\title{
PERTANGGUNGJAWABAN PIDANA TERHADAP PENCEMARAN LINGKUNGAN DI INDONESIA
}

\author{
I Komang Agus Edi Suryawan, I Nyoman Gede Sugiartha, I Nyoman Sutama \\ Fakultas Hukum Universitas Warmadewa, Denpasar-Bali, Indonesia \\ nyomansugiartha14@gmail.com, edysuryawan83@gmail.com, sutamainyoman62@gmail.com
}

\begin{abstract}
Abstrak
Lingkungan sebagai tempat untuk hidup dan sekaligus sebagai penampungan limbah dari kegiatan manusia. Lingkungan yang sehat dan bersih sangat penting, hal ini terjadi apabila limbah masyarakat tidak merusak lingkungan. Pencemaran lingkungan berdampak buruk bagi masyarakat. Penelitian ini bertujuan untuk menjelaskan pengaturan hukum terhadap tindak pidana pencemaran lingkungan dan menjelaskan pertanggungjawaban tindak pidana pencemaran lingkungan menurut hukum pidana di Indonesia. Penelitian ini didesain denagan penelitian hukum Normatif, dengan menggunakan pendekatan peraturan Perundang-Undangan melalui pengkajian terhadap produk Perundang-Undangan secara khusus yang mengatur tentang pencemaran lingkungan. Sumber bahan hukum yaitu bahan hukum primer, bahan hukum sekunder. Hasil penelitian menunjukkan bahwa pengaturan hukum tindak pidana pencemaran lingkungan diatur pada Undang-undang No.32 Tahun 2009 tentang Perlindungan dan Pengelolaan Lingkungan Hidup, selanjutnya pertanggungjawabannya dapat dikenakan terhadap individu, korporasi dan pejabat yang berwenang.
\end{abstract}

Kata kunci: Pertanggungjawaban, Pidana, Pencemaran Lingkungan

\begin{abstract}
The environment is a place to live and at the same time as storage for waste from human activities. A healthy and clean environment is very important, this will happen if community waste does not damage the environment. Environmental pollution has a bad impact on society. This study aims to explain the legal arrangements for environmental pollution crime and to explain the liability for environmental pollution crime according to criminal law in Indonesia. This research was designed with Normative legal research, using a statutory regulatory approach through an assessment of Legislation products specifically regulating environmental pollution. Sources of legal materials were primary legal materials, secondary legal materials. The results showed that the legal regulation of environmental pollution crime is regulated in Law No.32 of 2009 concerning Environmental Protection and Management, furthermore, the responsibility can be imposed on individuals, corporations, and authorized officials.
\end{abstract}

Keywords: Accountability, Criminal, Environmental pollution

\section{PENDAHULUAN}

Lingkungan diartikan sebagai tempat hidup serta sebagai wadah penampungan dari limbah kegiatan manusia. Lingkungan mempunyai kemampuan pencegahan dalam keadaan tertentu dan mengembalikan keadaan semula apabila limbah tersebut tetap berada di posisi batas yang mendukung lingkungan bersangkutan. Lingkungan mampu menerima limbah yang bersumber dari rumah masyarakat ataupun pabrik yang berada pada lingkungan tersebut. Tentunya ini menimbulkan terjadinya perubahan kualitas lingkungan hidup, seperti air, udara dan tanah serta tumbuh-tumbuhan, hewan dan mikroorganisme (Risjani, 2018).

Dalam Undang-Undang Dasar 1945 Pasal $28 \mathrm{H}$ ayat (1) menyatakan "setiap orang berhak hidup sejahtera lahir batin, bertempat tinggal dan mendapatkan lingkungan hidup yang baik dan sehat serta berhak memperoleh pelayanan kesehatan". Makna dari Undang-Undang Dasar 1945 ini nyata tujuannya yaitu keperluan untuk memiliki lingkungan nyaman dan sehat merupakan suatu bentuk hak asasi seseorang. Suatu Negara wajib memberikan kepastian,perlindungan serta keyakinan lingkungan yang sehat, karena olehnya negara wajib mempunyai keyakinan kuat dan terjamin dalam rangka melindungi dan mengelola serta menjaga lingkungan hidup (Ansari, 2014).

Pencemaran pada lingkungan hidup diartikan yaitu masuk atau sengaja dimasukkannya suatu makhluk hidup, energi, zat, serta komposisi lainya dalam suatu lingkungan hidup dari aktivitas 
manusia menyebabkan melampauinya standar mutu yang sudah diterapkan untuk lingkungan hidup. Selama seiring berjalannya waktu lingkungan telah menerima banyak limbah hasil dari manusia, manusia bisa saja menganggap membuang sekecil sampah itu tidak berarti tetapi apabila seluruh dunia melakukan itu maka sampah-sampah itu yang akan menjadi penyebab pencemaran lingkungan (Erwin, 2008).

Lingkungan hidup yang rusak akan berdampak pada masyarakat. Beberapa penelitian serta laporan dari lembaga lingkungan mencatat beberapa masalah dari lingkungan hidup sedang dialami Indonesia kini yaitu mulai air sungai keruh dan tercemar, air di sungai merupakan suatu hal penting untuk disimak sebab semua digunakan oleh warga. dimana kementerian lingkungan hidup dan kehutanan (KLHK) telah meninjau kualitas air di sungai dengan rutin. Dikonfirmasi menyatakan kualitas air di sungai pada wilayah sebagian saat ini diklasifikasikan kedalam keadaan tercemar parah. Sejumlah 671 yang ditinjau aliran sungai dalam tahun 2015 dan 2016, total sejumlah 17 aliran sungai yang kualitasnya tidak banyak perubahan, total sejumlah 211 aliran air sungai yang didapatkan kualitasnya cenderung membaik, akan tetapi total sebanyak 343 aliran sungai kualitas air yang tercemar sangat tajam. Aliran air sungai tersebut sudah tidak baik digunakan untuk wahana bermain air, pertanian, kebutuhan air untuk peternakan, membudidayakan ikan dan kebutuhan air minum (Roselin, 2019)

Tahun 2018 di daerah Wakatobi, dikagetkan karena kematian ikan paus sperma (physeter macrocephalus) total ukuran panjangnya 9,5 meter dan lebar badan sekitar 4 meter. Ditinjau dari hasil evakuasi yang dilaksanakan oleh regu dari Balai Taman Nasional Wakatobi tanggal 19 November 2018 ditemukan sampah di dalam perut paus yang kebanyakan plastik beratnya total mencapai 5,9 kg. dugaan kuat kematian pada ikan paus sperma tersebut diakibatkan oleh sampah plastik yang gagal dicerna dalam tubuh sehingga sampai saat ini (Paulus, 2020).

Berdasar pada kualitas lingkungan, biasanya dalam penakaran kualitas lingkungan bisa diteliti melalui parameter kimia, biologi dan fisika. Sesuai Undang-Undang Nomor 32 Tahun 2009 tentang perlindungan serta pengelolaan lingkungan hidup pada pasal 20 ayat (2) menyatakan kualitas lingkungan hidup tersusun atas kualitas air, kualitas air limbah, kualitas air laut, kualitas udara ambien, kualitas emisi, kualitas gangguan, dan kualitas lainnya dimana menyesuaikan perkembangan dari ilmu pengetahuan dimiliki manusia dan kecanggihan teknologi. Dimana yang paling terpenting dalam menunjang pertumbuhan ekonomi suatu kawasan yaitu sektor industri. Akan terjadi permasalahan yang besar, apabila perkembangan dunia industri tanpa memperhatikan lingkungan. Pada umumnya industri mengkonsumsi 37\% energi dan menghasilkan 50\% karbon dioksida, 90\% sulfur dioksida, serta bahan kimia beracun lainnya. Konsentrasi pada industri- industri besar di suatu wilayah mengakibatkan kerusakan lingkungan lokal dan lingkungan global yang parah. Pengalaman buruk ini telah dialami pada masa-masa beberapa puluhan tahun yang lalu (Machdar, 2018).

Lingkungan yang buruk sangat berdampak negatif pada kesehatan, kemudahan, efisiensi, kenikmatan hidup, keseimbangan ekosistem, serta keindahan dan sumber daya alam dari tercemarnya lingkungan akibat aktivitas masyarakat ataupun proses alam. Pengelolaan lingkungan hidup adalah upaya penting dalam pemanfaatan, pemeliharaan, pengendalian, penataan, pengawasan, pemulihan, dan pengembangan lingkungan hidup (Murniati, 2016). Oleh karenanya perlindungan dari lingkungan hidup memang hal terpenting jika menginginkan lingkungan yang nyaman, sehat dan berkesinambungan. Santoso, (2016) mengkaji tentang pertanggungjawaban pidana pencemaran lingkungan hidup yang dilakukan oleh korporasi. Menurut Dayani \& Pujiyono, (2017) Pertanggungjawaban pidana tindak pidana lingkungan hidup telah diatur dalam Undang-Undang Nomor 32 Tahun 2009 tentang perlindungan dan pengelolaan lingkungan hidup.

\section{METODE PENELITIAN}

Metode penelitian yang digunakan yaitu penelitian hukum Normatif, dengan pendekatan peraturan Perundang-undangan melalui pengkajian terhadap produk Perundang-Undangan secara khusus yang mengatur tentang pencemaran lingkungan. Adapun yang akan digunakan sumber bahan hukum yaitu berupa Bahan hukum primer, yaitu Undang-Undang Dasar Republik Indonesia tahun 1945; UndangUndang Republik Indonesia Nomor 32 Tahun 2009 tentang Perlindungan dan Pengelolaan Lingkungan Hidup; Peraturan Menteri Negara Lingkungan Hidup Republik Indonesia No. 17 Tahun 2012, tentang Pedoman Keterlibatan Masyarakat dalam Proses Analisis Dampak Lingkungan Hidup dan izin Lingkungan; Peraturan Pemerintah No. 27 Tahun 2012 tentang Izin Lingkungan; Kitab 
Undang-Undang Hukum Pidana (KUHP). Untuk bahan hukum sekunder yaitu bahan hukum yang diperoleh dari hasil pengkajian kepustakaan (library research) seperti buku-buku yang berkaitan dengan hukum; hasil penelitian ahli hukum, jurnal-jurnal hukum

\section{HASIL DAN PEMBAHASAN}

\section{Pengaturan Hukum Terhadap Tindak Pidana Pencemaran Lingkungan}

Tindakan manusia yang berlebihan di lingkungan wilayah Indonesia (setelah otonomi daerah) dimana pada saat iu berlomba-lomba agar dapat menguasai sumber daya alam untuk kepentingan pribadi dan golongan yang sebesar-besarnya untuk mendapatkan keuntungan yang sebanyak-banyaknya tanpa memperdulikan dampak negatif yang dapat diterima generasi sekarang dan generasi akan datang. Jika sudah demikian, sangat diperlukan fungsi kontrol dari sistem pemidanaan. Pengaturan pemidanaan terhadap tindak pidana lingkungan tertuju pada upaya untuk mendidik masyarakat, pengusaha, dan pemerintah sehubungan akibat kesalahan moral ditimbulkan yang berkaitan dengan sikap tindakan terhadap lingkungan hidup yang dilarang. Juga difungsikan untuk mencegah serta menghalangi bagi pelaku potensial supaya tidak melakukan tindakan yang tidak bertanggung jawab dan merusak terhadap lingkungan hidup.

Pengaturan pemidanaan dalam Undang-Undang No.32 Tahun 2009 tentang Perlindungan dan Pengelolaan Lingkungan Hidup (UUPPLH) dapat dikenakan terhadap individu, korporasi dan pejabat yang berwenang (Ruslan Renggong, 2018). Sebagaimana diatur pada Pasal 98, Tindak pidana lingkungan pada ayat (1) secara materiil dirumuskan yang artinya akan terjadi tindak pidana lingkungan jika ada akibat dari perbuatan yang dilakukan. ayat (2) ada unsur tambahan yaitu unsur mengakibatkan luka serius dan/atau bahaya terhadap kesehatan manusia. Unsur ini menjadi pemberat dari ayat (1) yang dilakukan sengaja. Pada ayat (3) unsur tambahannya yaitu korban dari pencemaran lingkungan itu luka sangat berat atau sampai mati maka ancaman pidana lebih berat dari ayat (1) dan ayat (2). Pasal 99, Rumusan pasal 99 juga merupakan rumusan materiil, artinya perbuatan pelaku menyebabkan terjadinya pencemaran dan/atau kerusakan lingkungan. Pasal 99 memiliki kesamaan dengan perumusan pasal 98 UUPPLH, hanya saja ancaman pidananya lebih ringan dibandingkan pasal 98. Pasal 100, Rumusan tindak pidana pasal 100 ayat (1) merupakan rumusan formil, yaitu tidak diperlukan adanya akibat perbuatan, bahwa perbuatan itu telah dilakukan sehingga terjadi pelanggaran kualitas air limbah, kualitas emisi, atau kualitas gangguan. Pada ayat (2) ketentuan pidana yang diatur dalam ayat (1) akan dapat diberikan kepada pelaku jika sanksi administratif tersebut telah dijatuhkan kepadanya atau pelaku sudah melakukan pelanggaran lebih dari satu kali. Dimaksud sanksi administratif yaitu pembekuan izin lingkungan, teguran tertulis, paksaan pemerintah serta dicabutnya izin lingkungan. Pasal 101, Rumusan tindak pidana lingkungan dalam pasal 101 dirumuskan secara formil, artinya perbuatan melepas suatu produk dari rekayasa genetik ke dalam lingkungan hidup telah dilakukan, maka tindak pidana lingkungan telah terjadi. Akibat dari perbuatan itu tidak perlu dicari, karena saat terjadi perbuatan kedalam media lingkungan sekitar melepaskan suatu produk dari rekayasa genetik telah terjadi tindak pidana lingkungan. Pasal 104, Dalam pasal 104 yaitu setiap orang dilarang melakukan perbuatan membuang limbah serta bahan berbahaya kedalam media dari lingkungan hidup tanpa memiliki izin. Limbah diartikan sebagai sisa suatu produk usaha dan/atau lain sebagainya. Adapun dumping yaitu perbuatan membuang, memasukkan, dan/atau menempatkan limbah serta bahan dalam konsentrasi, jumlah, lokasi dan waktu tertentu.

Pasal 105, Dalam pasal 105 bahwa setiap orang tidak boleh memasukkan limbah kedalam media lingkungan hidup Indonesia dimana asalnya dari luar jangkauan wilayah Negara Kesatuan Republik Indonesia. Ini dimaksudkan untuk melindungi Negara sebagai wadah pembuangan limbah sisa dari luar negeri. Karena Indonesia mempunyai wilayah yang cukup luas dan pulau-pulau yang tak berpenghuni dan kurangnya pengawasan. Pasal 112, Upaya melindungi lingkungan hidup, faktor pengawasan memiliki tujuan penting demi terwujudnya pelestarian fungsi lingkungan hidup. Karena itu, pejabat yang diberi kewenangan melakukan pengawasan wajib mengawasi ketaatan para pelaku usaha dan/atau kegiatan mentaati peraturan perundang-undangan yang berkaitan dengan perlindungan dan pengelolaan lingkungan serta izin lingkungan. 


\section{Pertanggungjawaban Tindak Pidana Pencemaran Lingkungan Menurut Hukum Pidana di Indonesia}

Menurut Moeljatno, sebagaimana dikutip oleh Ruslan Renggong, menggunakan istilah perbuatan pidana dalam mengartikan strafbaar feit, menyatakan tindak pidana merupakan oleh suatu aturan hukum perbuatan yang dilarang, bagi barang siapa melanggar larangan tersebut yaitu larangannya dibarengi dengan ancaman (sanksi) dengan pidana tertentu. perbuatan pidana yaitu perbuatan diatur oleh aturan hukumnya dilarang serta diancam dengan pidana, dimana perlu diingat yaitu larangan diartikan perbuatan (dimana kejadian atau keadaan yang diakibatkan dari perilaku seseorang), yang ditujukan terhadap pelaku yang menyebabkan kejadian itu disebut ancaman pidana. diantara larangan serta ancaman pidana memiliki hubungan yang erat, yang satu tidak dapat dipisahkan dari yang lain oleh sebab itu antara kejadian dan orang yang menimbulkan kejadian tersebut ada hubungan yang erat.

Sebagai perbandingan terhadap pengertian tindak pidana yang dikemukakan oleh para ahli hukum pidana tersebut, perlu kiranya mengartikan pengertian tindak pidana menurut pasal 11 ayat (1) RUU KUHP yang menentukan bahwa, tindak pidana merupakan kegiatan melakukan atau tidak melakukan sesuatu dimana diatur dalam peraturan perundang-undangan didefinisikan yaitu perbuatan dilarang serta diancam dengan pidana. Penegakan dari hukum pidana ini sebagai ultimum remedium atau upaya hukum yang terakhir dimana tujuannya yaitu untuk memberi hukuman kepada pelaku melalui hukuman penjara ataupun denda. Dalam penegakan hukum pidana bukan memiliki fungsi untuk memulihkan seperti semula lingkungan yang telah tercemar. melainkan, dengan penegakan dari hukum pidana ini dapat memberikan efek jera (deterrent factor) yang sangat ampuh. Oleh sebab itu, dalam penerapannya penegakan hukum pidana harus diterapkan secara efektif.

RKUHP Lingkungan memang berbeda dengan UUPPLH. Mulai dari total pasal ataupun ketentuan dari pasal yang mengatur. Ini merupakan yang menyebabkan pemicu masalah menyatakan tentang RKUHP Lingkungan cukup tidak terlalu serius perkuat undang-undang lama yang telah ada melainkan justru melemahkan. Pengertian Lex specialis derogat legi generali atau diartikan hukum yang bersifat khusus diutamakan dari hukum bersifat umum, berarti bahwa RKUHP Lingkungan dimana mengatur ketentuan umum bisa dikesampingkan oleh UUPPLH, dimana halnya undangundang yang mengatur dari ketentuan khusus. Secara umum, penegakan hukum pidana lingkungan melalui empat tahapan yakni tahapan penyidikan yang dilakukan oleh penyidik, tahapan penuntutan yang dilaksanakan oleh penuntut umum, tahapan pemeriksaan di pengadilan yang dilaksanakan oleh hakim pada semua tingkatan pengadilan dan tahapan eksekusi atau pelaksanaan putusan pengadilan yang dilakukan oleh jaksa.

Pada pasal 94 ayat (1) UUPPLH, diatur bahwa yang menjadi penyidik dalam tindak pidana lingkungan hidup adalah "Selain penyidik pejabat polisi Negara republik Indonesia, pejabat pegawai negeri sipil tertentu di lingkungan instansi pemerintah yang lingkup tugas dan tanggung jawabnya di bidang perlindungan dan pengelolaan lingkungan hidup diberi wewenang sebagai penyidik sebagaimana dimaksud dalam hukum acara pidana untuk melakukan penyidikan tindak pidana lingkungan hidup."

ebagaimana telah diuraikan diatas, selain penyidik polri juga diatur penyidik pejabat pegawai negeri sipil (PPNS) beserta kewenangannya. Dalam pasal 7 ayat (2) KUHAP ditentukan bahwa: "Penyidik sebagaimana dimaksud dalam pasal 6 ayat (1) huruf b mempunyai wewenang sesuai dengan undang-undang yang menjadi dasar hukumnya masing- masing dan dalam pelaksanaan tugasnya berada di bawah koordinasi dan pengawasan penyidik tersebut dalam pasal 6 ayat (1) huruf a."

Pada pasal 96 UUPPLH Pembuktian, dalam tuntutan tindak pidana lingkungan hidup alat bukti yang sah terdiri atas:

a. Keterangan dari saksi

b. Keterangan dari ahli

c. Surat tertentu;

d. Petunjuk tertentu;

e. Keterangan dari terdakwa;dan/atau

f. Alat bukti yang lain, termasuk juga alat bukti yang mana diatur didalam peraturan perundangundangan.

Dalam sistem peradilan pidana, pihak yang harus membuktikan kesalahan terdakwa pada persidangan pengadilan adalah penuntut umum. Menurut pasal 13 KUHAP, penuntut umum yaitu 
jaksa dengan diberi suatu wewenang oleh undang- undang ini dengan tujuan melaksanakan penuntutan serta melaksanakan penetapan dari hakim.

\section{SIMPULAN DAN SARAN \\ 1. Simpulan}

Berdasarkan hasil penelitian diketahui bahwa pengaturan hukum terhadap tindak pidana pencemaran lingkungan, berdasarkan dalam Pasal 98, Pasal 99, Pasal 100, Pasal 101, Pasal 104, Pasal 105, dan Pasal 112 Undang-Undang No. 32 Tahun 2009 tentang Perlindungan dan Pengelolaan Lingkungan Hidup (UUPPLH) dapat dikenakan terhadap individu, korporasi, dan pejabat yang berwenang, selanjutnya Pertanggungjawaban tindak pidana pencemaran lingkungan sebagai ultimum remedium istilahnya upaya hukum yang terakhir dimana tujuannya yaitu memberikan hukuman bagi para pelaku berupa hukuman penjara. Dalam penegakan hukum pidana lingkungan melalui empat tahapan yakni penyidikan, penuntutan, pemeriksaan, dan eksekusi. Dalam pasal 94 UU PPLH yang menjadi penyidik yaitu Pejabat Polisi Republik Indonesia dan Pejabat Pegawai Negeri Sipil, pada pasal 96 pembuktian, sahnya alat bukti yaitu keterangan saksi, keterangan seorang ahli, surat, petunjuk tertentu, keterangan dari terdakwa, serta alat bukti yang lainnya termasuk juga alat bukti yang dimana diatur dalam peraturan perundang-undangan. Dengan demikian, penegakan hukum pidana ini dapat memberikan efek jera (deterrent factor) yang sangat efektif.

\section{Saran}

Dari hasil penelitian di atas, adapu yang menjadi saran peneliti yaitu Bagi pemerintah atau pejabat yang berwenang apabila ada orang yang dengan sengaja melakukan perbuatan yang mengakibatkan kerusakan lingkungan, membuang limbah sembarangan menyebabkan orang lain luka dan/atau sangat bahaya terhadap kesehatan, harus ditindak tegas sesuai peraturan perundang- undangan yang berlaku. Hal ini bertujuan agar memberikan efek jera pada pelaku, selanjutnya bagi penegak hukum pertanggungjawaban pidana harus ditegakkan apabila orang yang dengan sengaja melakukan kerusakan lingkungan hingga menyebabkan pencemaran lingkungan dan merugikan banyak orang harus ditindak sesuai peraturan dan sanksi yang berlaku, sebagaimana khusus penghukuman tersebut bertujuan agar meminimalisir terjadinya tindakan kejahatan atau perbuatan merugikan yang tidak dikehendaki serta perilaku yang melanggar hukum.

\section{DAFTAR PUSTAKA}

Ansari, M. (2014). Implikasi Pengaturan Lingkungan Hidup terhadap Peraturan Perundang-Undangan dalam Kegiatan Bisnis (Perspektif Konstitusi). Jurnal Konstitusi, 11(2), 276-295.

Dayani, R. J., \& Pujiyono, A. . E. S. A. (2017). Pertanggungjawaban Pidana Korporasi Terhadap Pembuangan Limbah Ke Media Lingkungan Hidup Tanpa Izin (Studi Kasus Putusan Pengadilan Negeri Ungaran No.62/Pid.Sus/2013/Pn.Ung). Jurnal Law, 6(62), 1-15.

Erwin, M. (2008). Hukum Lingkungan. Bandung: Refika Aditama.

Machdar, I. (2018). Pengantar Pengendalian Pencemaran: Pencemaran air, Pencemaran udara, dan Kebisingan. Yogyakarata: Prenamedia.

Murniati. (2016). Akuntabilitas Pejabat Pengawas Lingkungan Hidup di Badan Lingkungan Hidup (BLH) Kabupaten Sigi. Jurnal Katalogis, 4(1), 114-126.

Paulus, N. T. J. H. (2020). Buku Ajar Pencemaran Laut. Yogyakarta: Deepublish.

Risjani, O. jufri dan Y. (2018). Indikator Pencemaran Lingkungan. Yogyakarta: Deepublish.

Roselin, D. M. dan R. (2019). Pemberdayaan Masyarakat. Yogyakarta: Deepublish.

Ruslan Renggong. (2018). Hukum Pidana Lingkungan. Jakarta: Prenadamedia.

Santoso, M. A. (2016). Pertanggungjawaban Pidana Pencemaran Lingkungan Hidup yang Dilakukan oleh Korporasi. Jurnal Cakrawala Hukum, 7(2), 216-228. 